\title{
Analysis on Causes and Management of International Investment Risk of Transnational Enterprises
}

\author{
Liyun Xu \\ Anhui University, Hefei, 230601, China
}

Keywords: transnational enterprise; international investment risk; cause; management

\begin{abstract}
In the era of rapid economic globalization, the establishment and development of transnational enterprises have also been expanding. In the process of international investment, the risk is constantly arising due to the influence of a variety of uncertain factors. Therefore, transnational enterprises must pay more attention to the investment risk during international investment. This paper focuses on the analysis and discussion of causes of investment risks encountered by transnational enterprises in international investment, and puts forward corresponding management measures, hoping to effectively help these companies effectively avoid the impact of international investment risks.
\end{abstract}

\section{Introduction}

In China, the management of transnational enterprises began in 1950s, and has been developing for seventy years. With the scale expansion of development, the field of investment is also extending. From finance, trade, transportation to manufacturing, many large-scale transnational enterprises with high technical levels and strong international competitiveness have been formed during the continuous development. At the same time, it is not a long time for most enterprises to explore international market, so there is no good strategy to limit the risk to the utmost during investment process. Different from domestic investment, international investment is influenced by economic and political factors of many countries, so that it is more difficult to manage investment risk.

\section{Connotation of International Investment Risk of Transnational Enterprises}

International investment risk mainly refers to the risk in the process of transnational investment due to the existence of a lot of uncertain factors that can lead to the failure of reaching the expected return on investment. During the process of investment, investment risk and investment return coexist, which leads to the uncertainty of investment results. In general, transnational companies firstly invest through domestic and international financing activities, mainly including three types of investment: the investment securities market, investment production project and investment and trade activities. In investment, not all projects can guarantee a certain profit. Therefore, the profitability and debt repayment ability of transnational enterprises are uncertain, and the multifaceted uncertainty leads to investment risk during international investment. ${ }^{[1]}$

\section{Main Reasons of International Investment Risks of Transnational Enterprises}

Before investing, it is necessary for transnational enterprises to analyze and assess the risk of the whole investment so as to make more insurance decisions. At present, there are four kinds of investment risks faced by transnational corporations, that is, interest rate risk, exchange rate risk, operational risk and national risk.

The occurrence of interest rate risk is mainly because that a variety of uncertain factors make the interest rate change in the process of investment, which result in investment devaluation or income loss. Interest rate risk is usually influenced by three aspects, namely, the change of different currency interest rates in different international financial markets, the change of interest rates in 
different countries, and the change of interest rates of loans, which are mainly reflected in the following aspects:

(1) When market interest rate is raised, the cost of raising funds of transnational enterprises will also increase, which reduces the profit of investment enterprises and the returns.

(2) In the process of stock investment, income is entirely dependent on the operating results of those invested enterprises. If enterprises have some problems in the process of operation, they must bear the loss of interest rate when the annual profit is lower than the market average interest rate.

(3) When new bonds are issued, the market interest rate is bound to rise and the interest rate of this new bond is also raised. In this case, debt of the lower interest rate will also fluctuate in price. Therefore, the original investor will inevitably be affected in income.

Exchange rate risk is mainly due to that the change of foreign exchange rate result in the increase of expenditures and liabilities of transnational corporations, making the risk of company assets and income decrease. Usually, there are two aspects:

(1) Under the influence of a variety of factors in the value of domestic currency, for a transnational enterprise involving external business, when the value of the domestic currency and the currency of the operating country is declining, some of the foreign-related business projects in the domestic enterprises will be converted by the accountant in terms of risk.

(2) In the process of investment management, if foreign governments freeze their own currency, it will lead to the inability to exchange currency with them and failure to recover the investment transaction and economic risk, which is also a kind of exchange rate risk.

Business risk in the broad sense usually refers to the political and economic risks encountered by the transnational corporations in the process of production and operation which include interest rate risk and foreign exchange risk. In the narrow sense, business risk usually means macro and micro market operational risk. Macro market operational risk includes market supply and demand risk, market competition risk, market order risk and market openness risk. In operational risk of transnational enterprises, it is mainly the risk of micro market operation which mainly includes production risk, price risk, sales risk, competition risk and reputation risk. ${ }^{[2]}$

National risk mainly refers to the risk which is brought by many uncertainties existing in legal politics in the investment countries and the society suffered by the investment and management of transnational enterprises. The key factor is the politics. Generally, political risk includes two aspects: the first is the dramatic change in the state's operating environment, which makes investment projects discontinuous in the process of operation. The second is that political rights and authority in the society are relatively complex which brings a certain influence on the investment. Usually, under the influence of political risk, investment management may be changed into "nationalization" or disguised "confiscation" of investment projects, which will bring a fatal blow to transnational enterprises.

\section{Management of International Investment Risk of Transnational Enterprises}

For various risks existing in the current international investment, transnational enterprises must take into consideration the risks brought by various factors, strengthen corresponding management, and deal with risks in advance.

In view of exchange rate risk often encountered by transnational corporations, we can strengthen management in the following aspects:

(1) In the process of international investment, through the way of loans from foreign banks and repaying with the income of investment, it is possible to avoid the situation of currency freeze and difficulties encountered in the exchange of funds.

(2) Through effective use of forward foreign exchange market, long term foreign currency swap transactions or foreign exchange trading can effectively avoid the occurrence of accounting conversion risk.

(3) The risk transfer in payment time can be realized by means of early or delayed payment.

In the process of international investment of transnational enterprises, the influence of interest rate on investment effect will be different because of different markets and different currencies. In 
general, influence is not obvious. Therefore, for transnational corporations, it is necessary to comprehensively analyze the change of market interest rate in time in the process of international investment so as to avoid the impact of interest rate risk. ${ }^{[3]}$

Operational risk is the main risk that transnational corporations are faced with in the course of production and operation. Therefore, we need to pay more attention. It is necessary to make corresponding preventive measures in advance to manage them effectively. Under normal circumstances, the following aspects of management strategies can be used to control it:

(1) Strategy to adapt to risks

This strategy is mainly used to address risks arising from policy changes. Transnational enterprises should always fully understand the relevant policies in the world so as to effectively serve the production and operation.

(2) Strategy to control risks

This strategy is mainly used for marketing channel risk, brain drain risk, fire risk and other unexpected risks. In order to avoid the risk of marketing channel, we must strictly control the quality of products so as to avoid safety accidents caused by quality problems, and deal with these problems effectively once they are found. In the management of talents, we are expected to make clear management, set up perfect work standards and clear work contents. At the same time, in the management process, it is necessary to stress the daily training of corporate culture, create a good corporate image, better retain talents and reduce brain drain. We must do a good job of daily safety check on the prevention of accident risk and strengthen the safety awareness of our staff.

(3) Strategy to diversify risks

Risk diversification strategy is to spread the overall risk into multiple projects through the development of various risk activities. During the process, risks are effectively dispersed. Thus, the total risks from multiple projects are less than the overall risks in one project, reducing losses caused by risk.

(4) Strategy to avoid risks

This strategy to avoid risk mainly aims at price risk and competitive strength risk. In the current extremely fierce market competition, as transnational companies, they must make a full analysis of competitors. SWOT mode is usually used for the analysis of competitors. Firstly, they should carefully analyze strengths and weaknesses of competitors and enterprises themselves, and then formulate a strong competitive strategy. When facing these opportunities, they are required to take out their most obvious advantages to compete with competitors. In the face of threats, they need to timely find the most effective strategy to deal with them. ${ }^{[4]}$

(1) In the process of international investment by transnational corporations, the most important thing is whether the political situation in the host country is stable. This is the key to the long-term stability of multinational investment in this country. Therefore, before multinational corporations make international investment, they must make a careful analysis on the political situation and political stability of the host country and whether there will be civil strife and war. The criteria for determining the stability of the countries' political situation usually include the following: First, whether the leadership members of the government of the country hold office stably for a long period of time, and whether there are certain factional disputes among them. These factors are preconditions for possible changes in the national political situation. The second aspect is that different demands for interests from different social strata usually lead to a certain amount of turbulence in the political situation of this country. Because of the contradiction of interests among each stratum, it is very likely to cause struggle and result in social unrest. The third aspect is the basic situation of ethnic groups and religions that exist in the country. If there is a constant struggle during a period, it will inevitably have an impact on the stability of the political situation. ${ }^{[5]}$ When transnational enterprises make international investments, once there is political instability in the host country, its development will suffer a fatal impact, leading to an investment failure.

(2) Strategy to diversify investment

Mainly through the investment of funds and diversification of several investment varieties in different stages, this strategy is able to provide a certain guarantee for reducing investment loss. 


\section{Conclusion}

With the accelerating process of economic globalization, the development of transnational enterprises is also progressing. However, due to the influence of many uncertain factors, they are facing more and more investment risks in the process of international investment. In view of these investment risks, they are required to timely and effectively analyze the causes and formulate the most effective management countermeasures according to specific conditions, so as to ensure that transnational enterprises can obtain greater profits in the process of investment and then promote the national economic development and construction.

\section{References}

[1] Zhao Beiwen. Location Choice of Chinese Enterprises' Foreign Direct Investment under the New Situation of Economic Globalization [J]. World Economic Research, 2015 (06): 119-126+129.

[2] Wang Jianguo. Causes and Management of International Investment Risks of Multinational Corporations-A Case Study of Mersha East Company [J]. The modern Business, 2018(18): 106-107.

[3] Kou Shunping, $\mathrm{Xu}$ Quan. Causes and Legal Measures to the Expansion of "Indirect Expropriation” in International Investment Field [J]. Modern Law, 2014, 36 (01): 136-145.

[4] The Yellow River, Starostin Nikita. The Political Risk and Control of Overseas Investment by Chinese Enterprises-A Case Study of Countries along the Belt and Road [J]. Journal of Shenzhen University (Humanities and Social Sciences Edition), 2016 / 01: 93-100).

[5] Zhang Youwen, Wu Xinkun. Factor Mobility in International Direct Investment and Resource Allocation in A Globalized Economy [J]. Academic Monthly, 2017, 49 (12): 78-89. 